\title{
DINAMIKA PERKEMBANGAN HIV/AIDS DI SULAWESI UTARA MENGGUNAKAN MODEL PERSAMAAN DIFERENSIAL NONLINEAR SIR (SUSCEPTIBLE, INFECTIOUS AND RECOVERED)
}

\author{
Amir Tjolleng ${ }^{\text {1) }}$, Hanny A. H. Komalig ${ }^{\text {1) }}$, Jantje D. Prang ${ }^{1)}$ \\ ${ }^{1)}$ Program Studi Matematika FMIPA Universitas Sam Ratulangi \\ Jl. Kampus Unsrat, Manado 95115 \\ e-mail : tjollengamir@ymail.com; hanny07@yahoo.com ; jantjedprang@yahoo.com
}

\begin{abstract}
ABSTRAK
Telah dilakukan penelitian untuk mengetahui dinamika perkembangan HIV/AIDS di Sulawesi Utara menggunakan model persamaan diferensial nonlinear SIR. Data yang digunakan adalah data jumlah penderita HIV/AIDS dan jumlah penduduk di Sulawesi Utara tahun 2007-2008 dari Badan Pusat Statistik dan Dinas Kesehatan Provinsi Sulawesi Utara. Hasil analisis kestabilan berdasarkan nilai eigen matriks Jacobi memperoleh satu titik tetap bebas penyakit yaitu $E=(S, I)=(526.315,0)$ yang bersifat semi stabil karena fenomena ambang batas dengan nilainilai eigen $\lambda_{1}=0$ dan $\lambda_{2}=0,32$. Bilangan reproduksi dasar penyakit HIV/AIDS di Sulut sebesar 4,155. Hasil ini menunjukkan bahwa akan terjadi epidemi penyakit HIV/AIDS dalam kurun waktu hingga 100 tahun ke depan.
\end{abstract}

Kata kunci : Bilangan Reproduksi Dasar, HIV/AIDS, Kestabilan, Model SIR

\section{THE DEVELOPMENT DYNAMIC OF HIV/AIDS IN NORTH SULAWESI USING NONLINEAR DIFFERENTIAL EQUATION MODEL OF SIR (SUSCEPTIBLE, INFECTIOUS AND RECOVERED)}

\begin{abstract}
The research has been conducted to determine the dynamics of the development of HIV/AIDS in North Sulawesi using SIR nonlinear differential equation model. The data is used on the number of people of HIV/AIDS and the number of residents in North Sulawesi in 2007-2008 from the Central Bureau of Statistics and the Health Official of North Sulawesi. Stability analysis results based on the eigenvalues of the Jacobi matrix obtained disease free equilibrium point is $E=(S, I)=(526.315,0)$ that are semi stable due to the threshold phenomenon with eigenvalues $\lambda_{1}=0$ and $\lambda_{2}=0,32$. The basic reproductive number of HIV/AIDS in North Sulawesi at 4,155. These results indicate the HIV/AIDS epidemic will cause within a period of up to 100 years into the future.
\end{abstract}

Keywords : Basic Reproductive Number, HIV/AIDS, Stability, SIR Model

\section{PENDAHULUAN}

Dewasa ini epidemi Human Immunodeficiency Virus (HIV) secara global masih menjadi masalah kesehatan yang serius sehingga menimbulkan kekhawatiran bagi manusia di belahan bumi. Epidemi HIV di Indonesia merupakan epidemi yang tercepat pertumbuhannya di Asia. Pada tahun 2004 hanya 16 dari 33 provinsi yang dilaporkan memiliki kasus infeksi HIV. Selanjutnya, di penghujung tahun 2009 kasus AIDS yang dilaporkan telah menyebar di 33 provinsi di Indonesia (Komisi AIDS Nasional, 2009).

Sulawesi Utara adalah daerah yang memiliki tingkat kasus AIDS tertinggi kelima di Indonesia yakni sebesar 24,54 (557 kasus) atau sekitar 2,2 kali angka nasional. Proporsi ini diperkirakan akan terus meningkat hingga beberapa tahun ke depan (Kemkes, 2011).

Penyakit HIV/AIDS dengan prediksi perkembangan jumlah penderita yang terinfeksi dapat dimodelkan dengan menggunakan model matematis epidemiologi 
yaitu model persamaan diferensial nonlinear SIR (Susceptible, Infectious and Recovered). Model tersebut pertama kali diperkenalkan pada tahun 1927 oleh Kermack dan McKendrick (Murray, 2002).

Dalam penelitian ini, model epidemi SIR digunakan untuk mengetahui dinamika perkembangan, titik kesetimbangan dan bilangan reproduksi dasar dari penyakit HIV/AIDS di Sulawesi Utara.

\section{TINJAUAN PUSTAKA}

\section{Model Epidemi SIR}

Murray (2002) dan Chaharborj et al. (2010) menjelaskan bahwa model epidemi SIR pertama kali diperkenalkan oleh Kermack dan McKendrick pada tahun 1927. Model tersebut terdiri dari tiga kategori yaitu: susceptible (S) atau individu yang rentan terserang penyakit, infected (I) atau individu yang terinfeksi dan dapat menyebarkan penyakit tersebut kepada individu yang rentan dan recovered $(\mathrm{R})$ atau individu yang diasumsikan telah sembuh atau kekebalan tubuhnya telah kembali normal sehingga kebal terhadap penyakit.

Model epidemi SIR diasumsikan sebagai berikut :

$$
\begin{aligned}
& \frac{d S}{d t}=-r S I \\
& \frac{d I}{d t}=r S I-a I \\
& \frac{d R}{d t}=a I
\end{aligned}
$$

dimana :

$S=$ jumlah individu yang rentan dalam populasi pada waktu $t$

$I=$ jumlah individu yang terinfeksi dalam populasi pada waktu $t$

$R=$ jumlah individu yang sembuh dalam populasi pada waktu $t$

$a=$ laju kesembuhan dari infectious menjadi recovered

$r=$ laju penularan penyakit dari susceptible menjadi infectious

\section{Sistem Persamaan Diferensial Biasa Nonlinear}

Suatu persamaan diferensial biasa nonlinear adalah persamaan diferensial biasa yang tak linear. Misalkan suatu sistem persamaan diferensial biasa dinyatakan sebagai :

$$
\dot{x}=\frac{d x}{d t}=f(t, x)
$$

$$
\begin{aligned}
& \text { dengan } x=\left[\begin{array}{c}
x_{1}(t) \\
x_{2}(t) \\
\vdots \\
x_{n}(t)
\end{array}\right] \\
& \operatorname{dan} f(x, t)=\left[\begin{array}{c}
f_{1}\left(t, x_{1}, x_{2}, \ldots, x_{n}\right) \\
f_{2}\left(t, x_{1}, x_{2}, \ldots, x_{n}\right) \\
\vdots \\
f_{n}\left(t, x_{1}, x_{2}, \ldots, x_{n}\right)
\end{array}\right]
\end{aligned}
$$

adalah fungsi tak linear dalam $x_{1}, x_{2}, \ldots, x_{n}$. Sistem persamaan (4) disebut sistem persamaan diferensial biasa nonlinear (Braun, 1983).

\section{Linearisasi}

Misalkan diberikan sistem persamaan diferensial biasa nonlinear berikut:

$$
\dot{x}=f(x), x \in R^{n}
$$

dengan $x(t) \in R^{n}$ adalah suatu fungsi bernilai vektor dalam $t$ dan $f: U \rightarrow R^{n}$ adalah suatu fungsi mulus yang terdefinisi pada subhimpunan $U \subset R^{n}$.

Dengan menggunakan ekspansi Taylor di sekitar titik tetap $\bar{x}$, maka sistem persamaan (5) dapat ditulis sebagai berikut :

$$
\dot{x}=\dot{\eta}=J \eta+\varphi(\eta)
$$

dengan $J$ adalah matriks Jacobi yang dinyatakan sebagai berikut :

$$
J=\frac{\partial f(\bar{x})}{\partial x}=\left[\begin{array}{cccc}
\frac{\partial f_{1}}{\partial x_{1}} & \frac{\partial f_{1}}{\partial x_{2}} & \cdots & \frac{\partial f_{1}}{\partial x_{n}} \\
\frac{\partial f_{2}}{\partial x_{1}} & \frac{\partial f_{2}}{\partial x_{2}} & \cdots & \frac{\partial f_{2}}{\partial x_{n}} \\
\vdots & \vdots & & \vdots \\
\frac{\partial f_{n}}{\partial x_{1}} & \frac{\partial f_{n}}{\partial x_{2}} & \cdots & \frac{\partial f_{n}}{\partial x_{n}}
\end{array}\right]_{\bar{x}}
$$

dan $\varphi(\eta)$ adalah suku berorde tinggi yang bersifat $\quad \lim _{\eta \rightarrow 0} \varphi(\eta)=0, \quad$ dengan $\eta=x-\bar{x} . \quad J \eta$ pada sistem persamaan (6) disebut pelinearan sistem persamaan (5) (Tu, 1994).

\section{Nilai Eigen dan Vektor Eigen}

Diberikan matriks koefisien konstan $A$ berukuran $n \times n$ dan sistem persamaan diferensial biasa homogen $\dot{x}=A x, x(0)=$ $x_{0}, \boldsymbol{x} \in R^{n}$. Suatu vektor tak nol $\boldsymbol{x}$ di dalam $R^{n}$ disebut vektor eigen dari $A$ jika untuk suatu skalar $\lambda$ berlaku: $A x=\lambda \boldsymbol{x}$

Nilai skalar $\lambda$ dinamakan nilai eigen dari $A$. 
Untuk mencari nilai $\lambda$ dari $A$, maka sistem persamaan (7) dapat ditulis: $(A-\lambda I) x=0$

dengan $I$ adalah matriks identitas. Sistem persamaan (8) mempunyai solusi tak nol jika dan hanya jika

$$
P(\lambda)=|A-\lambda I|=0
$$

Persamaan (9) merupakan persamaan karakteristik matriks $A$ (Anton, 1995).

\section{Kestabilan Titik Tetap}

Misalkan diberikan sistem persamaan diferensial biasa sebarang $\dot{x}=f(x), x \in R^{n}$. Titik $\bar{x}$ disebut titik tetap jika $f(\bar{x})=0$. Titik tetap disebut juga titik kritis atau titik kesetimbangan ( $\mathrm{Tu}, 1994)$.

Misalkan terdapat sistem persamaan diferensial linear $\dot{x}=A x \quad$ dengan $A=\left[\begin{array}{cc}k & l \\ m & n\end{array}\right] \quad$ mempunyai persamaan karakteristik $\quad \lambda^{2}-\tau \lambda+\delta=0 \quad$ dimana $\tau=k+n$ dan $\delta=\operatorname{det}(A)=k n-m l$. Nilai eigen dari $A$ adalah :

$$
\lambda_{1,2}=\frac{1}{2}\left(\tau \pm \sqrt{\tau^{2}-4 \delta}\right)
$$

Kestabilan titik tetap $\bar{x}$ dapat ditentukan dengan memperhatikan nilai-nilai eigen, yaitu $\lambda_{i}$ dimana $i=1,2, \ldots, n$ yang diperoleh dari persamaan karakteristik. Secara umum, kestabilan titik mempunyai perilaku sebagai berikut:

1. Stabil, jika :

a) Setiap nilai eigen real adalah negatif $\left(\lambda_{i}<0\right.$ untuk semua $\left.i\right)$

b) Setiap komponen bagian real dari nilai eigen kompleks, lebih kecil atau sama dengan nol $\left(\operatorname{Re}\left(\lambda_{i}\right) \leq 0\right.$ untuk semua $i)$.

2. Tidak stabil, jika :

a. Terdapat nilai eigen real yang positif $\left(\lambda_{i}>0\right)$ untuk suatu $i$.

b. Ada komponen bagian real dari nilai eigen kompleks, lebih besar dari nol $\left(\operatorname{Re}\left(\lambda_{i}\right)>0\right.$ untuk suatu $\left.i\right)$.

3. Sadel atau pelana, jika perkalian dua buah nilai eigen real sembarang adalah negatif $\left(\lambda_{i} \lambda_{j}<0\right.$ untuk $i$ dan $j$ sembarang). Titik tetap sadel ini bersifat tak stabil (Tu, 1994).

4. Jika salah satu nilai eigen yang diperoleh bernilai nol $\left(\lambda_{1}=0, \lambda_{2} \neq 1\right)$ maka titik tetapnya akan berada dalam suatu garis. Jika $\lambda_{2}<0$ maka semua solusi yang tidak dimulai dari titik tetap ini cenderung untuk bergerak menuju garis tersebut. Dan sebaliknya, jika $\lambda_{2}>0$ maka akan bergerak menjauhi garis tersebut (Farlow, 1994).

\section{Bilangan Reproduksi Dasar}

Bilangan reproduksi dasar merupakan bilangan yang menunjukkan jumlah individu rentan yang dapat menderita penyakit yang disebabkan oleh satu individu terinfeksi. Bilangan reproduksi dasar dilambangkan dengan $R_{0}$ dan dinyatakan dengan persamaan (11) berikut :

$$
R_{0}=\frac{r}{a} N=\frac{r}{a} S_{0}
$$

Beberapa kondisi yang akan timbul, yaitu :

1. Jika $R_{0}<1$, maka penyakit akan menghilang.

2. Jika $R_{0}=1$, maka penyakit akan menetap.

3. Jika $R_{0}>1$, maka penyakit akan meningkat menjadi wabah (Giesecke, 1994).

\section{METODOLOGI PENELITIAN}

\section{Data}

Penelitian ini menggunakan data sekunder tentang jumlah penderita HIV/AIDS dan jumlah penduduk di Provinsi Sulawesi Utara tahun 2007-2008 yang diperoleh dari Badan Pusat Statistik (BPS) dan Dinas Kesehatan Provinsi Sulawesi Utara.

\section{Prosedur Penelitian}

Adapun prosedur yang akan dilakukan dalam penelitian ini adalah sebagai berikut :

1. Menaksir parameter laju perubahan individu pada subpopulasi S (Susceptible), I (Infected) dan R (Recovered).

2. Menentukan titik tetap model.

3. Melakukan analisis kestabilan dengan metode linearisasi.

4. Menentukan bilangan reproduksi dasar $\left(R_{0}\right)$.

5. Membuat plot subpopulasi S, I dan R serta potret fase sistem dengan menggunakan software Maple 12.

\section{HASIL DAN PEMBAHASAN}

\section{Penentuan Parameter Model SIR}

Data yang digunakan untuk menentukan parameter tersebut adalah data 
jumlah penderita AIDS dan jumlah penderita yang meninggal pada tahun 2007-2008.

Tabel 1. Jumlah Penderita HIV/AIDS di Sulawesi Utara Tahun 2007-2008

\begin{tabular}{|c|c|c|c|}
\hline \multirow{2}{*}{ Tahun } & \multicolumn{3}{|c|}{ Jumlah Kasus yang Ditemukan } \\
\cline { 2 - 4 } & HIV & AIDS & Meninggal \\
\hline 2007 & 29 & 43 & 11 \\
\hline 2008 & 55 & 93 & 20 \\
\hline
\end{tabular}

Dari tabel di atas diperoleh :

$S(0)=S(2007)=2.186 .810=N$

$S(t)=S(2008)=2.186 .727$

$R(t)=R(2008)=20$

dimana $N$ menyatakan jumlah penduduk Sulawesi Utara pada tahun 2007 yang berjumlah 2.186.810 jiwa. Dengan mensubstitusi semua variabel di atas pada solusi khusus subpopulasi S yakni

$S(t)=S(0) e^{-\frac{R(t)}{\rho}}=S(0) e^{-\frac{R(t) r}{a}}$

diperoleh $\frac{r}{a}=1,9 \times 10^{-6}$.

Dengan asumsi laju kesembuhan atau kematian seorang penderita HIV/AIDS dalam 10 tahun sebesar $\frac{1}{10}$ diperoleh $a=10^{-1}=$ 0,1 dan $r=1,9 \times 10^{-7}$. Artinya laju kesembuhan dari individu terinfeksi HIV/AIDS menjadi sembuh atau meninggal di Sulawesi Utara berdasarkan data 2007-2008 sebesar 0,1 dan laju penularan penyakit dari individu rentan menjadi terinfeksi sebesar $1,9 \times 10^{-7}$.

\section{Penentuan Titik Tetap}

Setelah dilakukan penurunan dan perhitungan diperoleh titik tetap model yaitu $E(S, I)=E\left(\frac{a}{r}, 0\right)=E\left(\frac{0,1}{1,9 \times 10^{-7}}, 0\right)=$ $E(526.315,0)$.

Titik tetap yang diperoleh merupakan titik tetap bebas penyakit (diseases free equilibrium) atau suatu keadaan dimana tidak terjadi penyebaran penyakit menular dalam populasi karena jumlah subpopulasi individu terinfeksi pada waktu $t$ sama dengan nol.

\section{Analisis Kestabilan Titik Tetap}

Berdasarkan nilai eigen dari matriks Jacobi yang diperoleh dari metode linearisasi diperoleh nilai eigen yang bernilai $\lambda_{1}=0$ dan $\lambda_{2}=r S-a$.

Nilai eigen $\lambda_{1}=0$ menunjukkan arah kestabilan yang netral sepanjang sumbu titik tetap. Sedangkan untuk nilai eigen $\lambda_{2}=r S-a$ terdapat dua kondisi yang mungkin yakni :

1. $\lambda_{2}=r S-a$ akan bernilai positif jika $S>\frac{a}{r}$

2. $\lambda_{2}=r S-a$ akan bernilai negatif jika $S<\frac{a}{r}$

Jika nilai parameter dan variabel yang telah diperoleh melalui analisis data disubsitusikan ke $\lambda_{2}=r S-a$ maka akan didapatkan nilai eigen yang bernilai positif yaitu $\lambda_{2}=0,32$.

Jika salah satu nilai eigen yang diperoleh bernilai nol $\left(\lambda_{1}=0, \lambda_{2} \neq 1\right)$ maka pada kondisi tersebut, titik tetapnya berada dalam suatu garis. Karena nilai $\lambda_{2}=0,32$ maka semua solusi yang tidak dimulai dari titik tetap akan cenderung untuk bergerak menjauhi garis tersebut. Titik tetap bebas penyakit yang diperoleh bersifat semi stabil.

Potret fase dari titik tetap $E$ disajikan seperti pada gambar 1 berikut ini.

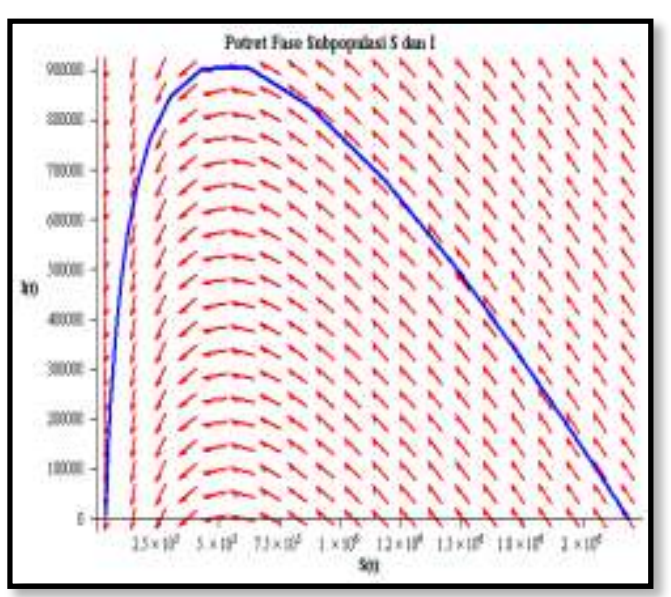

Gambar 1. Potret fase subpopulasi $S$ dan $I$

Melalui gambar 1 dapat dilihat bahwa beberapa segmen garis berwarna merah yang menunjukkan kemiringan (slope) $\frac{\mathrm{d} I}{\mathrm{dS}}$ dari penyelesaian di setiap titik $(\mathrm{S}, \mathrm{I})$ bergerak menjauhi garis sepanjang titik tetap (sumbu $S$ ) ketika $S>\frac{a}{r}$ seiring bertambahnya waktu. Keadaan titik tetap dalam daerah $S>\frac{\mathrm{a}}{\mathrm{r}}$ ini akan bersifat tidak stabil karena menghasilkan salah satu nilai eigen yang bernilai $\lambda>0$. Selanjutnya, beberapa segmen garis yang lain akan bergerak mendekati garis titik tetap ketika $S<\frac{a}{r}$. Keadaan titik tetap dalam daerah $S<\frac{a}{r}$ akan bersifat stabil karena menghasilkan salah satu nilai eigen 
yang bernilai $\lambda<0$. Ini berarti dalam daerah stabil, jumlah individu rentan dan terinfeksi tidak akan berubah secara signifikan.

Gambar 1 juga menunjukkan suatu fenomena ambang batas (threshold phenomenon). Jika jumlah individu subpopulasi rentan pada waktu awal $(\mathrm{S}(0)=\mathrm{N})$ memiliki nilai lebih kecil dari $\mathrm{S}=\frac{\mathrm{a}}{\mathrm{r}}=526.315$ maka tidak akan terjadi epidemi penyakit, begitu pun sebaliknya.

Jumlah individu subpopulasi rentan HIV/AIDS di Sulut pada tahun 2007 (S(0)) sebanyak 2.186.810. Jumlah ini ternyata lebih besar dari nilai parameter kritis yaitu $\mathrm{S}=\frac{\mathrm{a}}{\mathrm{r}}=526.315$. Hasil ini menunjukkan bahwa penyakit HIV/AIDS di Sulawesi Utara akan meningkat menjadi wabah atau menyebabkan terjadinya epidemi dalam kurun waktu tertentu di masa yang akan datang.

\section{Penentuan Bilangan Reproduksi Dasar}

Bilangan reproduksi dasar $\left(R_{0}\right)$ yang diperoleh yaitu $R_{0}=4,155$. Ini berarti satu individu terinfeksi (infectious) rata-rata dapat menularkan penyakit kepada empat hingga lima individu rentan (susceptible) dalam populasi. Nilai bilangan reproduksi dasar $\left(R_{0}\right)$ yang diperoleh lebih besar dari 1 . Ini menunjukkan bahwa. penyakit HIV/AIDS di Sulawesi Utara akan meningkat menjadi wabah dalam kurun waktu tertentu.

\section{Plot Perubahan Subpopulasi S, I dan R Terhadap Waktu}

Plot perubahan subpopulasi S, I dan $\mathrm{R}$ menggunakan nilai parameter dan variabel yang diasumsikan sebagai berikut :

$a=0,1 ; r=0,00000019$;

$N(0)=N(2007)=2.186 .810$;

$S(0)=S(2007)=2.186 .810$;

$S(t)=S(2008)=2.186 .727$

$I(0)=I(2007)=43$;

$I(t)=I(2008)=93$;

$R(0)=R(2007)=11$;

$R(t)=R(2008)=20$

Model dinamika penyebaran

HIV/AIDS di Sulut dapat diasumsikan sebagai berikut :

$\frac{d S}{d t}=2.186 .810-1,9 \times 10^{-7} S(t) I(t)$;

$\frac{d I}{d t}=1,9 \times 10^{-7} S(t) I(t)-0,1 I(t)$; $\frac{d R}{d t}=0,1 I(t)$

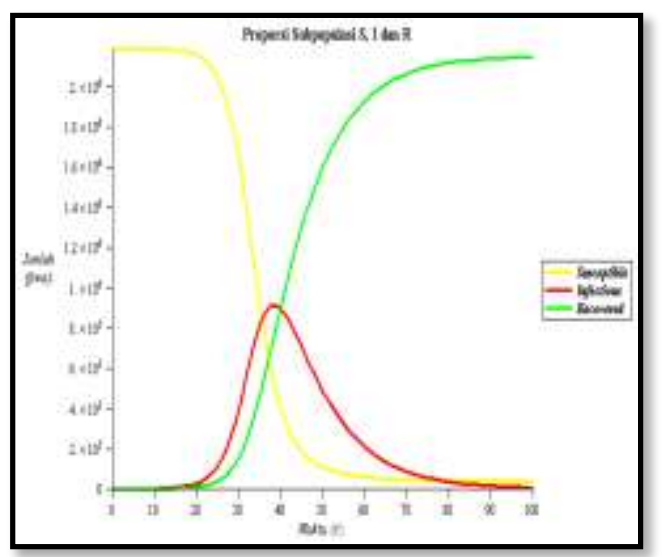

Gambar 2. Proporsi subpopulasi S, I dan R untuk $0 \leq t \leq 100$

Gambar 2 menjelaskan bahwa pada waktu $t \leq 100$ tahun, jumlah individu rentan semakin berkurang sedangkan jumlah individu terinfeksi dan meninggal mengalami kenaikan seiring berjalannya waktu. Hal ini disebabkan karena individu yang berada dalam subpopulasi rentan telah terinfeksi penyakit dan berpindah pada kategori subpopulasi individu terinfeksi.

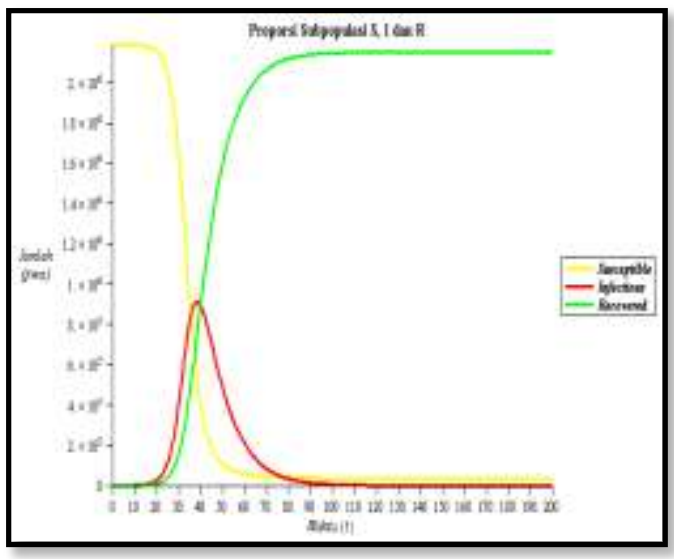

Gambar 3. Proporsi subpopulasi S, I dan R untuk $0 \leq t \leq 200$

Gambar 3 menunjukkan bahwa pada saat $t>100$ tahun, jumlah individu subpopulasi rentan, terinfeksi dan meninggal tidak mengalami perubahan yang signifikan. Kondisi ini disebut dengan kondisi stabil dari sistem. Kondisi stabil tersebut dicapai oleh sistem saat $E=(S, I)=(526.315,0)$. Oleh karena itu, penyakit HIV/AIDS di Sulawesi Utara akan bersifat endemik dalam kurun waktu 100 tahun ke depan. 


\section{KESIMPULAN}

Hasil model dinamika perkembangan HIV/AIDS di Sulawesi Utara menggunakan model SIR diperoleh parameter-parameter sebagai berikut :

$\frac{d S}{d t}=2.186 .810-1,9 \times 10^{-7} S(t) I(t)$,

$\frac{d I}{d t}=1,9 \times 10^{-7} S(t) I(t)-0,1 I(t)$ dan

$\frac{d R}{d t}=0,1 I(t)$.

Melalui analisis kestabilan berdasarkan nilai eigen matriks Jacobi diperoleh satu titik tetap bebas penyakit (diseases free equilibrium) yaitu $E=(S, I)=(526.315,0)$ yang bersifat semi stabil karena fenomena ambang batas dengan nilai-nilai eigen $\lambda_{1}=0$ dan $\lambda_{2}=0,32$.

Bilangan reproduksi dasar penyakit HIV/AIDS di Sulawesi Utara sebesar 4,155. Hasil ini menunjukkan bahwa penyakit HIV/AIDS di Sulawesi Utara akan meningkat menjadi wabah atau menyebabkan terjadinya epidemi dalam kurun waktu hingga 100 tahun ke depan.

\section{DAFTAR PUSTAKA}

Anton, H. 1995. Aljabar Linier Elementer. Edisi ke-5. Terjemahan Pantur Silababan dan I Nyoman Susila. Erlangga, Jakarta.

Braun, M. 1983. Differential Equations and Their Applications. Springer Verlag, New York.
Chaharborj, S. S., et al. 2010. Behavior Stability in Two SIR-Style Models for HIV. Int. Journal of Math Analysis. 4(9) : 427-434.

Farlow, S. J. 1994. An Introduction to Differential Equations and Their Applications. Mc. Graw-Hill, Inc.

Giesecke, J. 1994. Modern Infectious Disease Epidemiology. Oxford University Press, New York.

Kementerian Kesehatan R.I., Dirjen Pengendalian Penyakit dan Penyehatan Lingkungan. 2011. Laporan Situasi Perkembangan HIV \& AIDS di Indonesia sampai dengan Juni 2011. Jakarta Pusat

Komisi AIDS Nasional. 2009. Republic of Indonesia Country Report on the Follow up to the Declaration of Commitment on HIV/AIDS (UNGASS): Reporting Period 2008-2009. Jakarta.

Murray, J. D. 2002. Mathematical Biology: An Introduction. Third Edition. Springer-Verlag, New York Berlin Heidelberg.

Tu, P.N.V. 1994. Dynamical System : An Introduction with Applications in Economics and Biology. SpringerVerlag, New York. 